\title{
Earthquake Monitoring Using Variometric GPS Data Processing
}

\author{
Mokhamad Nur Cahyadi, Ririn Wuri Rahayu, Buldan Muslim
}

\begin{abstract}
Variometric Approach for Standalone Engine Displacement Analysis (VADASE) is a technique used in seismology purposes using GPS measurements. VADASE is used to determine the small displacement from the earthquake. The VADASE L1 solution is using the klobuchar ionospheric model. In this study VADASE was used in earthquakes with magnitudes $>7$ to $>9$ righter scales. In the scale of the earthquake category> 9 used Indian Ocean earthquake of December 26, 2016 with the strength of 9.1 SR by using the closest SAMP station and the Japanese Tohoku earthquake of March 11, 2011 with a power of 9.1 SR using 4 different stations namely MIZU, KMSV, TSK2 and Knii. The earthquake category with a scale of $>8$ SR is the offshore earthquake Bio Bio, Chile on February 27, 2010 with a power of 8.8 SR using 2 stations namely ANTC and SANT, the Bengkulu Indonesia earthquake on 12 September 2007 with a power of 8.4 SR using the SAMP station, an illaper earthquake, chile September 162015 with 8.3 SR using SANT station, and Tres Piscos earthquake - Mexico on September 8, 2017 with a power of 8.2 SR using IENG station. Earthquake with a strength of $>7$ SR, namely the amberlay-New Zealand earthquake on November 13, 2016 with a strength of 7.8 SR using MRLL and WGTN stations, Puerto quello-chile earthquake on December 25, 2016 with a strength of 7.6 SR using COYQ station, Java sea earthquake -Indonesia on 8 August 2007 with 7.5 SR power using BAKO station and ayula mexico earthquake on 19 september 2017 with 7.1 SR power using INEG station. From the results of VADASE, the farthest distance from the epicenter to the observation station is $1100 \mathrm{~km}$ (INEG station) and the closest distance is $95 \mathrm{~km}$ (BAKO station). The highest speed is $0.12 \mathrm{~m} / \mathrm{s}$ after 5 minutes from the earthquake in the earthquake Offshore Bio Bio-Chile 2010 uses the SANT station and the lowest speed is $0.006 \mathrm{~m} / \mathrm{s}$ after 10 minutes from the earthquake in the 2007 Bengkulu earthquake using the SAMP station. Whereas in the other earthquakes was the 2011 Tohoku earthquake with a speed of $0.06 \mathrm{~m} / \mathrm{s}$ after 1 minute using MIZU station, the amberley-New Zealand earthquake 2016 with a speed of $0.015 \mathrm{~m} / \mathrm{s}$ after 1 minute using the MRLI satellite, Puerto quello- earthquake Chile 2016 with a speed of $0.025 \mathrm{~m} / \mathrm{s}$ after 40 minutes using the COYQ satellite.
\end{abstract}

Keywords: VADASE, Earth quake, Deformation velocity

\section{Preface}

Variometrric Approach for Standalone Engine Displacement Analysis (VADASE) is a technique used in seismology purposes using GPS measurements. VADASE is used to determine the small displacement of the earthquake. The VADASE L1 solution is using the klobuchar ionospheric model. VADASE is proposed because it is an innovative strategy in GNSS data processing that uses the VADASE algorithm. VADASE is able to estimate in real time the speed and displacement in a global reference frame (ITRF), using introductory phase observation and high-speed broadcast products (1 $\mathrm{Hz}$ or more) (orbit, clock) collected by stand-alone GNSS receivers, achieving transfer accuracy in $1-2 \mathrm{~cm}$ (usually better) for intervals of up to several minutes. VADASE can be used in real time even on the GNSS receiver board. VADASE can display time and waveform changes caused by earthquakes with accuracy can only be achieved with seismometers or with other 2 GNSS approaches such as Precise Point Positionong (PPP) and Differential Positioning (DP). In this study VADASE is used to monitor changes in velocity after an earthquake which is divided into several categories based on earthquake magnitude, namely strength $>9 \mathrm{SR}$, earthquake strength $>$
$8 \mathrm{SR}$, and earthquake strength $>7 \mathrm{SR}$. By removing the nearest GPS station to the earthquake it can be used to determine the velocity of each earthquake to the nearest station. For earthquake category with magnitude $>9$ SR using the Indian / Aceh oceanic earthquake in 2004 using the SAMP station, the Japanese Tohoku earthquake in 2011 using MIZU, KMSV, TSK2 and KGNI stations. For the earthquake category with magnitude $>8 \mathrm{SR}$, using Chile's Bio Bio earthquake in 2010 using ANTC station and SANT station, for the Bengkulu-Indonesia earthquake in 2007 using the SAMP station, for the 2015 Illapel-Chile earthquake using the SANT station, the Tres Picos earthquake -Mexico in 2017 using IENG station. Earthquake with a strength of $>7$ SR using the Amberley earthquake. Vadase is used to determine the speed of displacement of $\mathrm{x}, \mathrm{y}$ and $\mathrm{z}$ at the time of the earthquake.

\section{Result and Discussion}

\subsection{Magnitude of earthquake $>9 \mathrm{SR}$}

\subsubsection{Earthquake of Samudera Hindia / Aceh - Indonesia 2004 (9,1 SR)}

Corresponding author: cahyadi_geod@yahoo.com 
The Indian Ocean earthquake struck in 26 December 2016 at 00:58:53 UTC, The quake which had the power of 9.1 $\mathrm{SR}$ was centered on $3,295^{\circ} \mathrm{N}-95,982^{\circ} \mathrm{E}$.

By using samp station data, the following velocity values are generated:

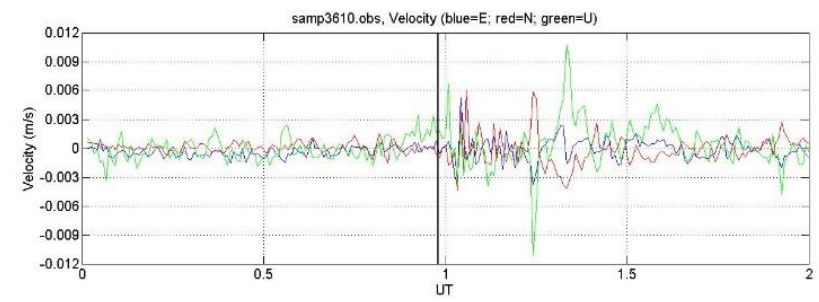

Fig. 1. Results values of Velocity station samp at 00 UTC - 02 UTC

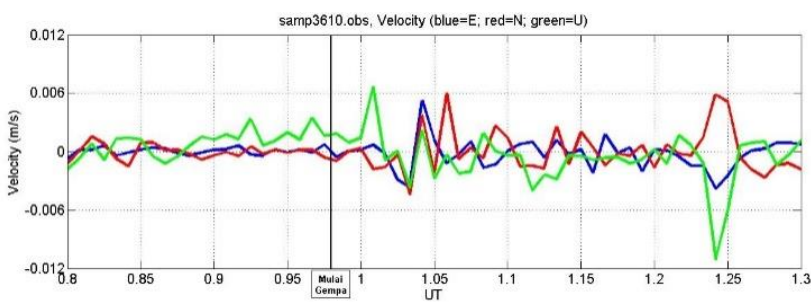

Fig. 2. Results values of Velocity station samp in CID

\subsubsection{Earthquake Tohoku - Jepang 2011 (9,1 SR)}

The Tohoku earthquake occurred on March 11, 2011 at 5:46:24 UTC. An earthquake centered on $38,297^{\circ} \mathrm{N}$ $142,373^{\circ} \mathrm{E}$ with a depth of $29 \mathrm{~km}$ has a power of $9.1 \mathrm{SR}$.

In the case of the Tobuk earthquake, the GPS data used came from observations of 4 different stations. The GPS station used is:

- Station mizu, with distance from the epicenter \pm 142 $\mathrm{km}$

- Station kmsv, with distance from the epicenter \pm 300 $\mathrm{km}$

- Station tsk2, with distance from the epicenter \pm 310 $\mathrm{km}$

- Station kgni, with distance from the epicenter \pm 385 $\mathrm{km}$

The following are the results of variometric processing in the 2011 Tobok earthquake:

a) Station Mizu (distance from the epicenter $\pm 142 \mathrm{~km}$ )

Mizu station observation data in the event of an earthquake, only recorded until 05:59:30 UTC. This station began operating again on March 15, 2011.

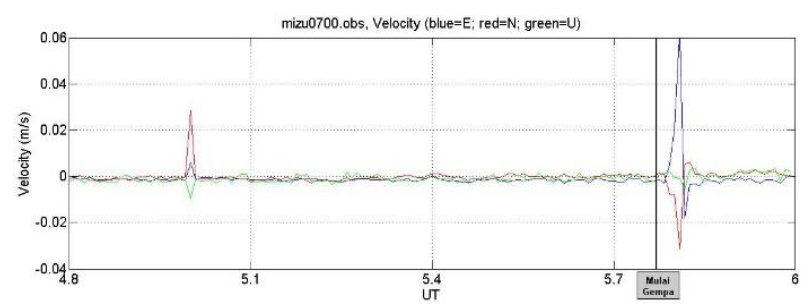

Fig. 3. Results of the value of the Velocity mizu station at 4.8 UTC - 6 UTC

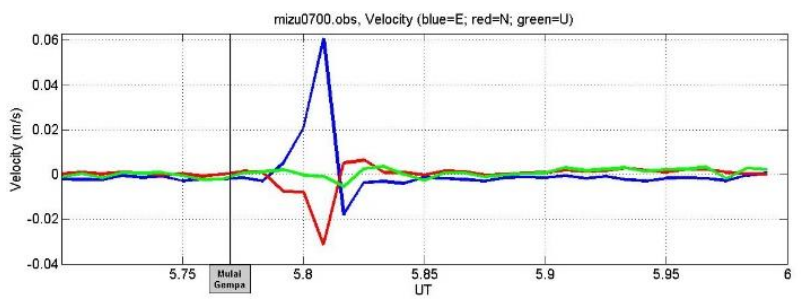

Fig. 4. Results of the value of the Velocity of the Mizu Station when the earthquake occurred

b) Station ksmv (distance from the epicenter $\pm 300 \mathrm{~km}$ )

On the Ksmv station data at 5:50 p.m. to 8:58 p.m. is not available. So at that hour the resulting variometric value is equal to 0 .

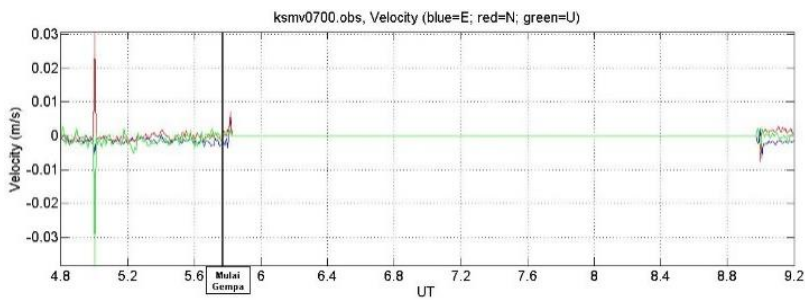

Fig. 5. Results of velocity of ksmv station at 4.8 UTC - 9.2 UTC

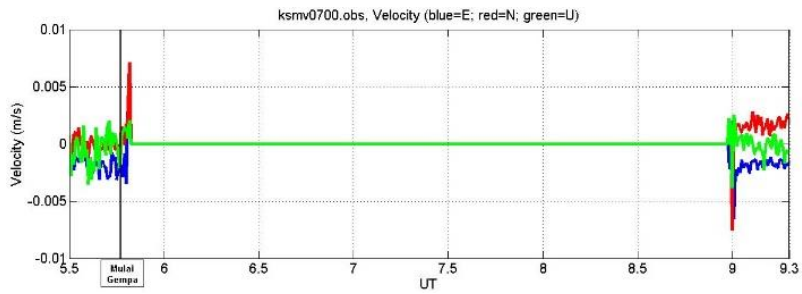

Fig. 6. Results of the value of Velocity ksmv station when an earthquake occurs

c) Station tsk2 (distance from the epicenter $\pm 316 \mathrm{~km}$ )

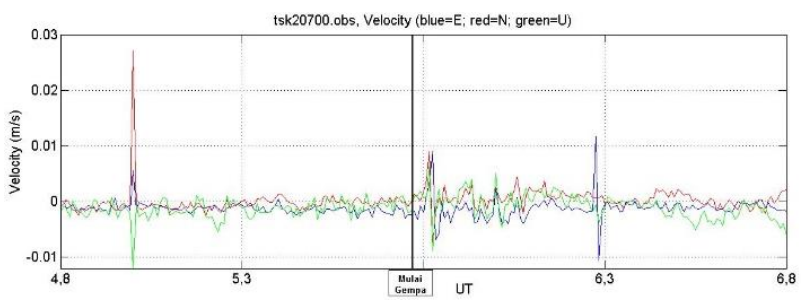

Fig. 7. Results of the value of Velocity tsk2 station at 4.8 UTC - 6.8 UTC

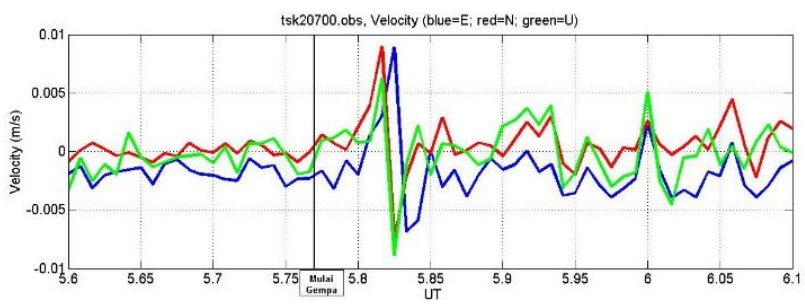

Fig. 8. Results of the value of Velocity tsk2 station when the earthquake occurred

d) Station kgni (distance from the epicenter $\pm 385 \mathrm{~km}$ ) 


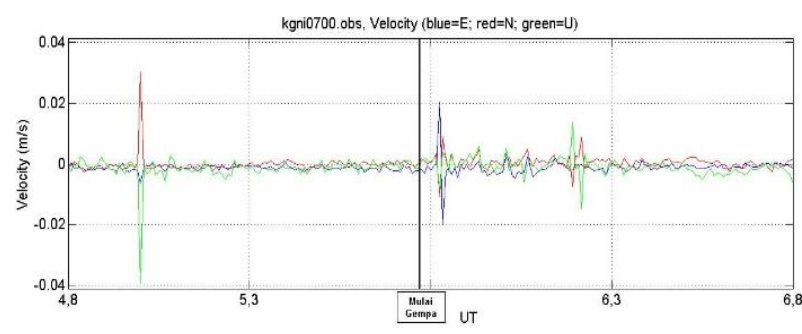

Fig. 9. The results of the value of the Velocity kgni station at 4.8 UTC - 6.8 UTC

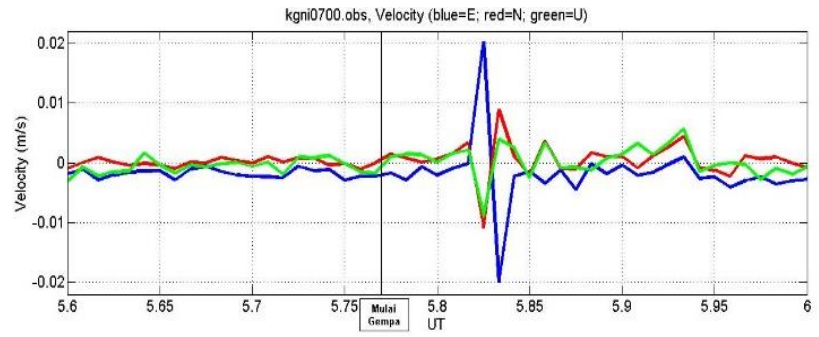

Fig. 10. The results of the value of the kg station Velocity when the earthquake occurred

\subsection{Magnitude of earthquake $>8 \mathrm{SR}$}

\subsubsection{Earthquake Offshore Bio Bio - Chile 2010 (8,8 SR)}

An earthquake at Bio Bio Offshore, Chile occurred on February 27, 2010 at 6:34:11 UTC. An earthquake centered on $36.122^{\circ} \mathrm{S}-72.889^{\circ} \mathrm{W}$ with a depth of 22.9 $\mathrm{km}$ has a power of $8.8 \mathrm{SR}$.

In the case of the above earthquake, the GPS data used came from observations of 2 different stations. The GPS station used is:

- Station antc, distance from the epicenter $\pm 180 \mathrm{~km}$

- Station sant, distance from the epicenter $\pm 380 \mathrm{~km}$

Here are the results of variometric processing in the 2010 Chile earthquake:

a) Station antc (distance from the epicenter $\pm 180 \mathrm{~km}$ )

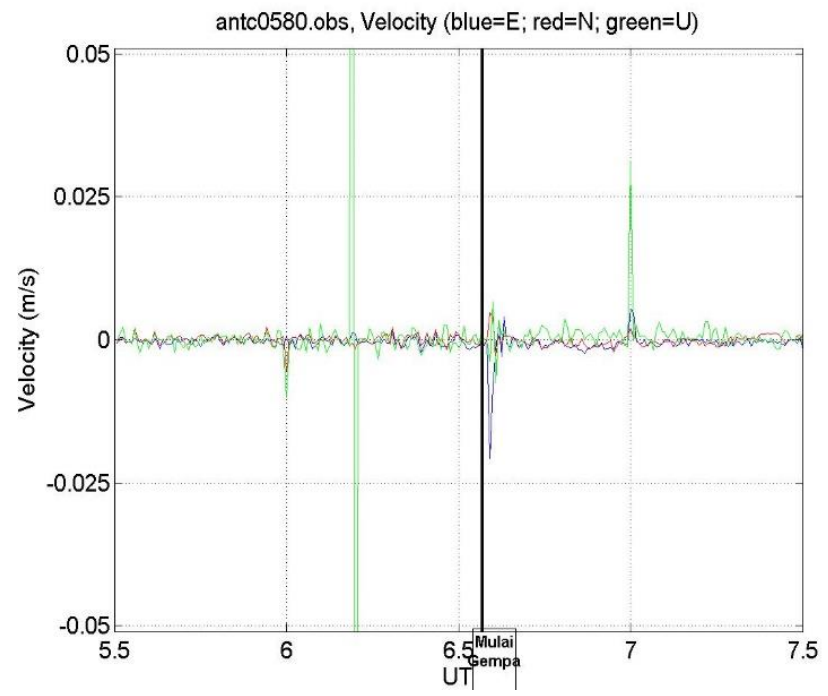

Fig. 11. Results of the value of the velocity of the antc station at 5.5 UTC - 7.5 UTC

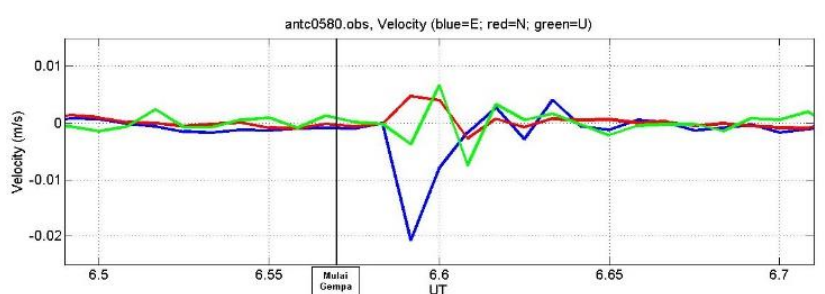

Fig. 12. Results of the value of the Velocity of the antc station when an earthquake occurs

b) Station sant (distance from the epicenter $\pm 380 \mathrm{~km}$ )

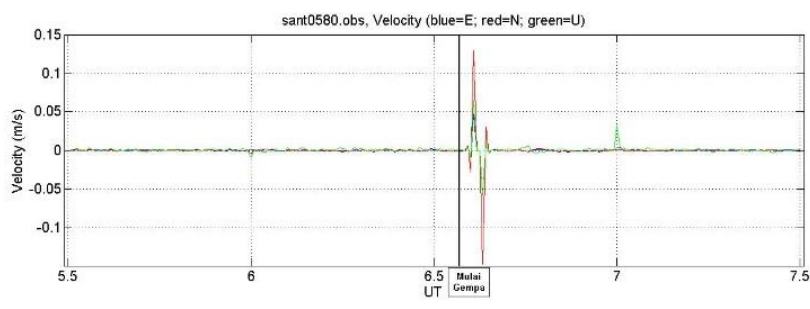

Fig. 13. Results of Velocity sant station at 5.5 UTC - 7.5 UTC

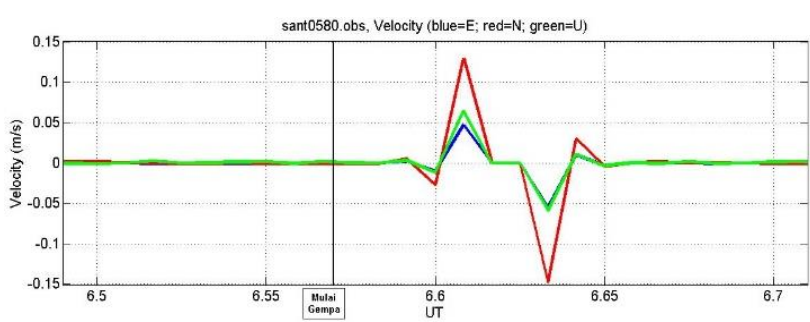

Fig. 14. Results of Velocity values of sant stations when an earthquake occurred

\subsubsection{Earthquake Bengkulu - Indonesia 2007 (8,4 $S R$}

Bengkulu Earthquake on 12 September 2007 at 11:10:26 UTC, the earthquake which has a power of 8.4 SR was centered at $4.438^{\circ} \mathrm{S}-101.336^{\circ} \mathrm{E}$ with a depth of $34 \mathrm{Km}$.

By using samp station data, the following velocity values are generated:

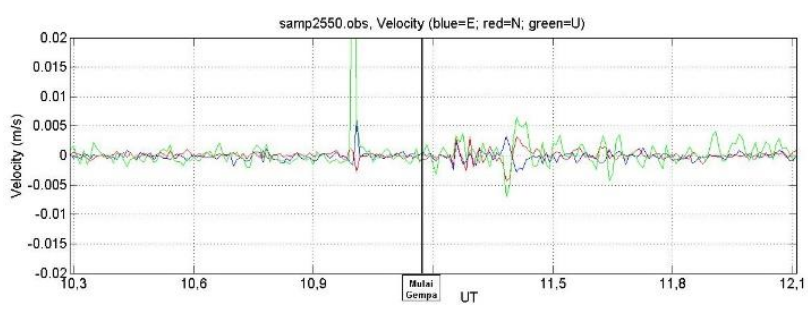

Fig. 15. Results of the Velocity samp station at 10.3 UTC - 12.1 UTC

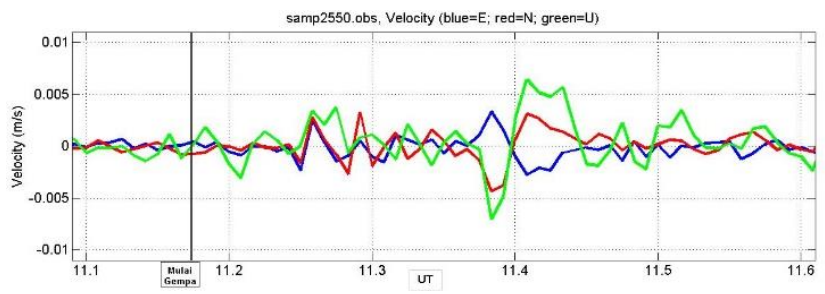

Fig. 16. Results the value of the Velocity station until the earthquake occurs 


\subsubsection{Earthquake Illapel - Chile 2015 (8,3 SR)}

Illapel Earthquake, Chile on 16 September 2015 at 22:54:32 UTC, the 8.3 SR earthquake was centered at $31,573{ }^{\circ} \mathrm{S}-71,674^{\circ} \mathrm{W}$ with a depth of $22,4 \mathrm{Km}$.

By using sant station data, the velocity value is generated:

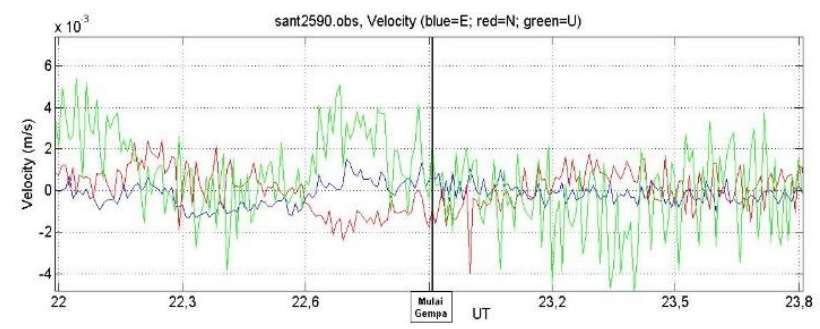

Fig. 17. Results of Velocity sant station at 22 UTC - 23.8 UTC

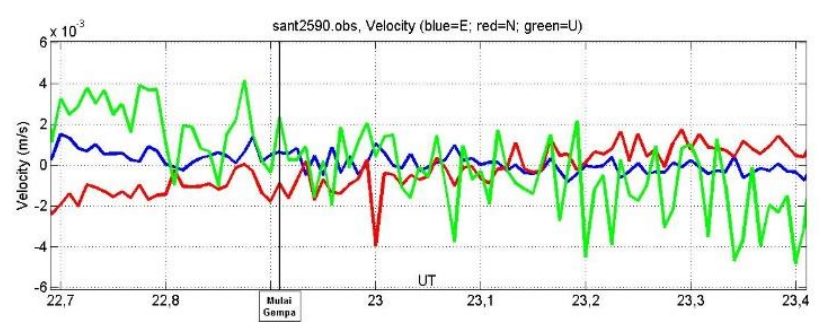

Fig. 18. Results of Velocity values of sant stations when an earthquake occurred

\subsubsection{Earthquake Tres Picos - Mexico 2017 (8,2 SR)}

Earthquake Tres Picos, Mexico on September 8, 2017 at 04:09:19 UTC, the 8.2 SR earthquake was centered at $15,022^{\circ} \mathrm{N}-93,899^{\circ} \mathrm{W}$ with a depth of $47,4 \mathrm{Km}$.

By using ieng station data, the following velocity values are generated:

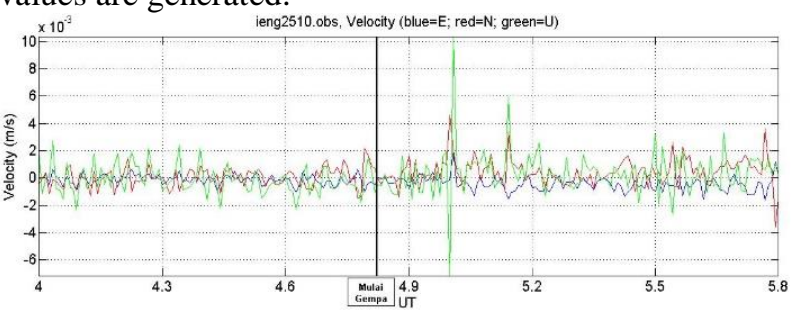

Fig. 19. Results of the velocity of ieng station at 4 UTC -5.8 UTC

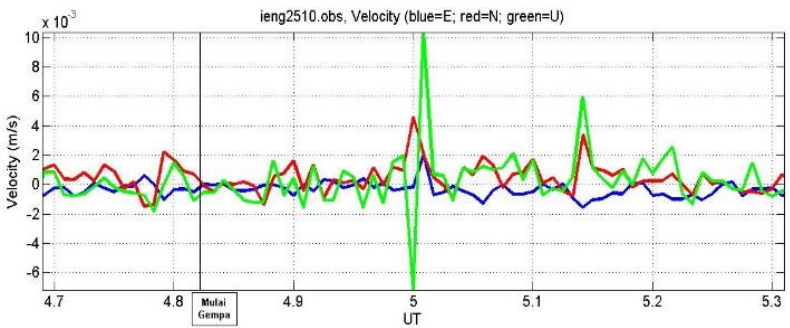

Fig. 20. Results of the velocity of the ieng station when the earthquake occurred

\subsection{Magnitude of earthquake $>7 \mathrm{SR}$}

2.3.1 Earthquake Amberley - New Zealand 2016 $(7,8 S R)$
The earthquake in Amberley, New Zealand occurred on November 13, 2016 at 11:02:56 UTC. The earthquake centered on $42.737^{\circ} \mathrm{S}-173.054^{\circ} \mathrm{E}$ with a depth of 15.1 $\mathrm{km}$ has a power of $7.8 \mathrm{SR}$.

In the case of the above earthquake, the GPS data used came from observations of 2 different stations. The GPS station used is:

- Station mrl1, distance from the epicenter \pm 140 $\mathrm{km}$

- Station wgnt, distance from the epicenter \pm 210 $\mathrm{km}$

Here are the results of variometric processing in the 2016 New Zealand earthquake:

a) Station mrl1 (distance from the epicenter $\pm 140 \mathrm{~km}$ )

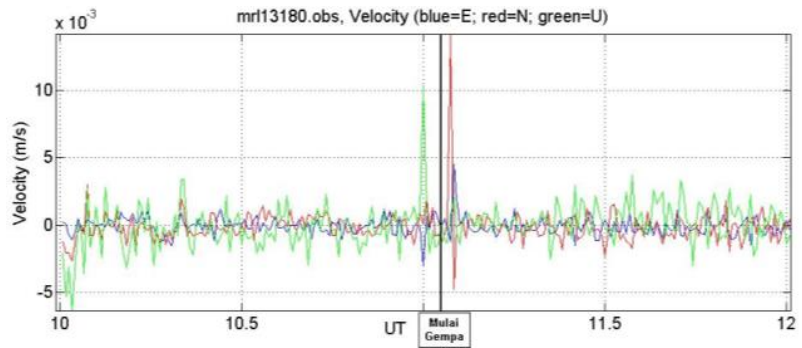

Fig. 21. The results of the Velocity station value are 1 to 10 UTC -12 UTC

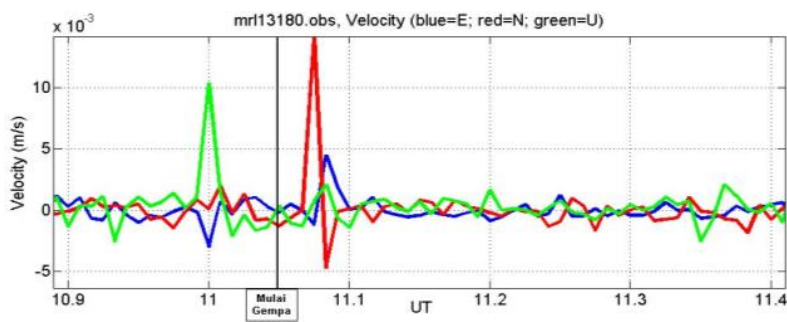

Fig. 22. Result of Velocity station mrll when earthquake occurred

b) Station wgtn (distance from the epicenter $\pm 210 \mathrm{~km}$ )

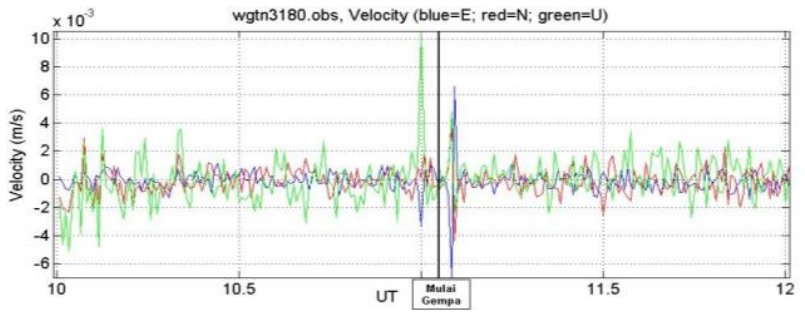

Fig. 23. Results of Velocity station values at 10 UTC - 12 UTC



Fig. 24. Results of the value of Velocity wgtn station when an earthquake occurs 


\subsubsection{Earthquake Puerto Quello - Chile 2016 (7,6 $S R)$}

Earthquake Puerto Quello, Chile on December 25, 2016 at 14:22:27 UTC, the earthquake with a magnitude of 7.6 SR was centered at $43.406^{\circ} \mathrm{S}-73.941^{\circ} \mathrm{W}$ with a depth of $38 \mathrm{Km}$.

By using coyq station data, the following velocity values are generated :

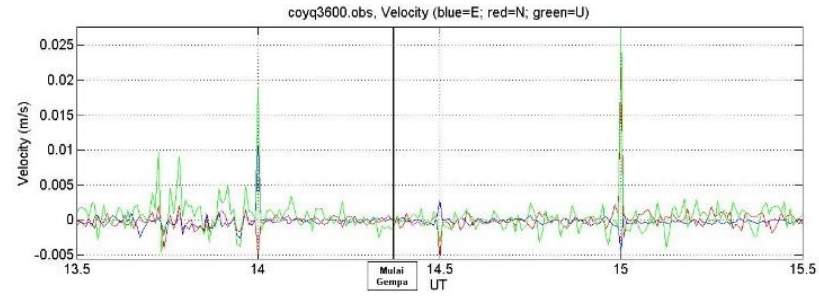

Fig. 25. Results of the Velocity coyq station at 13.5 UTC - 15.5 UTC

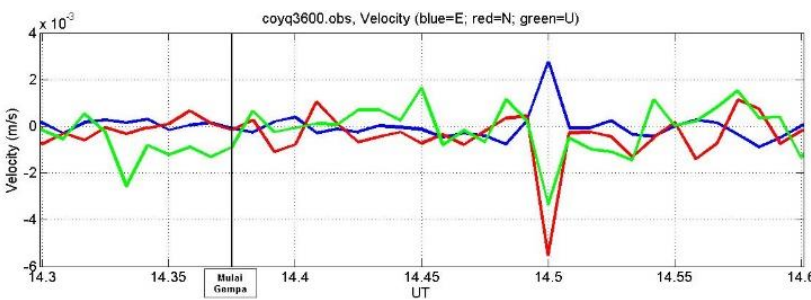

Fig. 26. Results of the value of Velocity coyg station when an earthquake occurs

\subsubsection{Earthquake Laut Jawa - Indonesia 2007 (7,5 $S R)$}

Earthquake in the Java Sea, Indonesia on August 8, 2007 at 5:05 p.m. UTC, The earthquake with a magnitude of $7.5 \mathrm{SR}$ was centered at $5,859^{\circ} \mathrm{S}-107,419^{\circ} \mathrm{S}$ with a depth of $280 \mathrm{Km}$.

By using the bako station data, the following velocity values are generated:

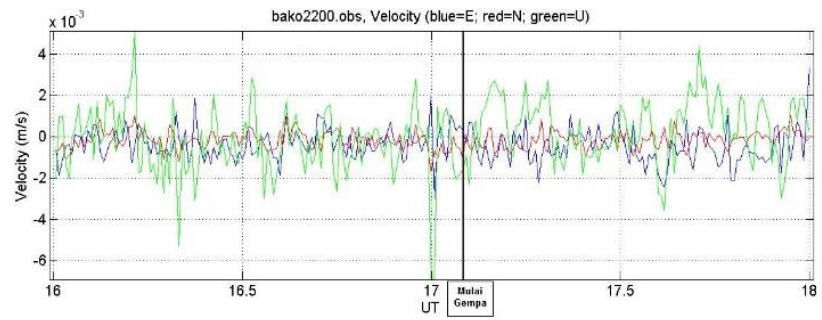

Fig. 27. Results of the value of Velocity bako station at 16 UTC - 18 UTC

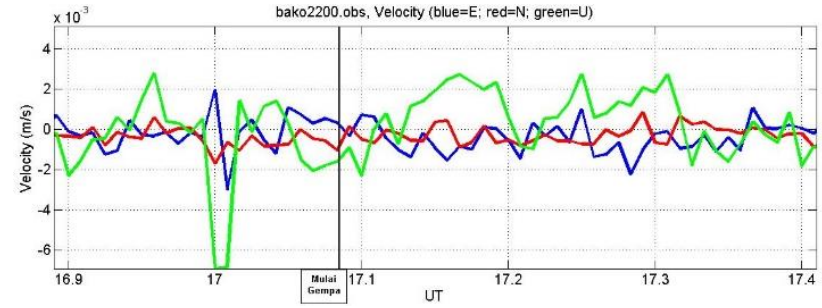

Fig. 28. Results of the value of the Velocity of the bako station when the earthquake occurred

\subsubsection{Earthquake Ayula - Mexico 2017 (7,1 SR)}

Earthquake in Ayutla, Mexico on September 19, 2017 at 18:14:38 UTC, the earthquake with a magnitude of 7.1 SR was centered at $18,550^{\circ} \mathrm{N}-98,489^{\circ} \mathrm{W}$ with a depth of $48 \mathrm{Km}$.

By using the ineg station data, the following velocity values are generated:

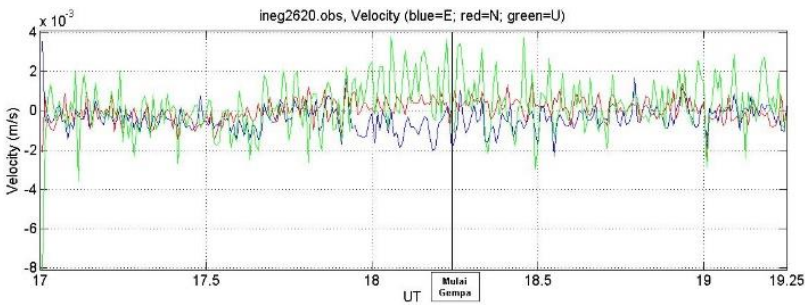

Fig. 29. The results of the Velocity ineg station at 17 UTC 19.25 UTC

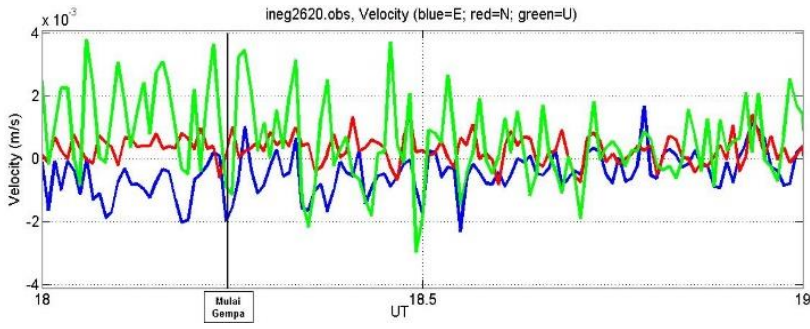

Fig. 30. Results of the velocity of the station ineg when the earthquake occurred

\section{Earthquake Detection Table to GNSS Station}

\begin{tabular}{|c|c|c|c|}
\hline No & Stasiun & $\begin{array}{c}\text { Jarak Epicenter } \\
\text { ke stasiun (Km) }\end{array}$ & $\begin{array}{c}\text { Delay waktu deteksi } \\
\text { efek gempa ke stasiun } \\
\text { GNSS (menit) }\end{array}$ \\
\hline 1 & samp & \pm 835 & 10 \\
\hline 2 & mizu & \pm 142 & 1 \\
\hline 3 & kmsv & \pm 300 & 2 \\
\hline 4 & tsk2 & \pm 310 & 3 \\
\hline 5 & kgni & \pm 385 & 3 \\
\hline 6 & antc & \pm 180 & 1 \\
\hline 7 & sant & \pm 380 & 2 \\
\hline 8 & samp & \pm 940 & 12 \\
\hline 9 & sant & \pm 198 & 5 \\
\hline 10 & ineg & \pm 1100 & 10 \\
\hline 11 & mrl1 & \pm 140 & 1,2 \\
\hline 12 & wgtn & \pm 210 & 7 \\
\hline 13 & coyq & \pm 285 & 1 \\
\hline 14 & bako & \pm 95 & \\
\hline
\end{tabular}

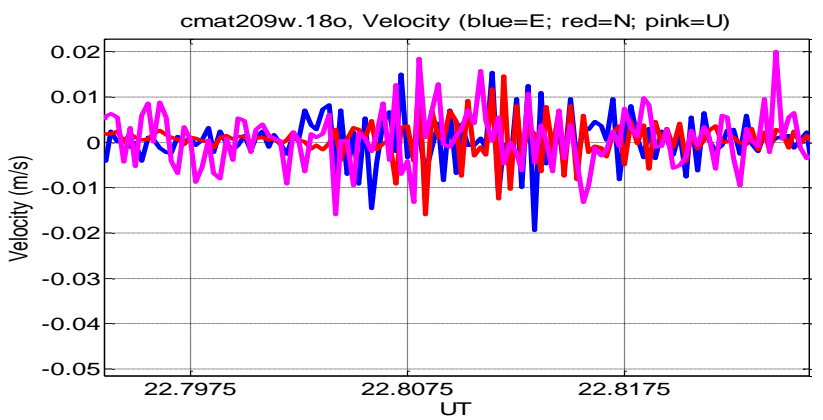




\section{References}

1. Branzanti, Mara. Software Defined receivers in GNSS scientific application: variometric approach to exploit GNSS-SDR phase observation. Geomatics workbooks n 12-FOSS4G Europe Como. (2015)

2. Benedetti, E. GNSS Seismology for the $2012 \mathrm{Mw}=$ 6.1 Emilia Earthquacke: exploiting the VADASE algorithm. From PDF SRL-D-13-00094-esupp. (2012)

3. Fratarcangeli, Francesca. VADASE reliability and accuracy of real time displacement estimation: application to the central Italy 2016 eathquackes. Remote Sensing article. (2018)

4. Malia, Leonor Mendoza. Near Real-Time High-Rate GPS Data Analysis for Earthquacke and Tsunami Early Warning. Jerman. (2015)

5. Viiti, Alfonso \& Augusto Mazzoni. Variometric approach for displacement analyss using Galileo data: first result. Geophysical research abstract vol. 19 EGU2017-5195. (2017) 